\title{
Litter drives ecosystem and plant community changes in cattail invasion
}

\author{
Emily C. Farrer ${ }^{1}$ and Deborah E. Goldberg \\ Department of Ecology and Evolutionary Biology, University of Michigan, Ann Arbor, Michigan 48109 USA
}

\begin{abstract}
Invaded systems are commonly associated with a change in ecosystem processes and a decline in native species diversity; however, many different causal pathways linking invasion, ecosystem change, and native species decline could produce this pattern. The initial driver of environmental change may be anthropogenic, or it may be the invader itself; and the mechanism behind native species decline may be the human-induced environmental change, competition from the invader, or invader-induced environmental change (non-trophic effects). We examined applicability of each of these alternate pathways in Great Lakes coastal marshes invaded by hybrid cattail (Typha $\times$ glauca). In a survey including transects in three marshes, we found that $T . \times$ glauca was associated with locally high soil nutrients, low light, and large amounts of litter, and that native diversity was highest in areas of shallow litter depth. We tested whether live $T$. $\times$ glauca plants or their litter induced changes in the environment and in diversity with a live plant and litter transplant experiment. After one year, Typha litter increased soil $\mathrm{NH}_{4}^{+}$and $\mathrm{N}$ mineralization twofold, lowered light levels, and decreased the abundance and diversity of native plants, while live Typha plants had no effect on the environment or on native plants. This suggests that $T . \times$ glauca, through its litter production, can cause the changes in ecosystem processes that we commonly attribute to anthropogenic nutrient loading and that $T . \times$ glauca does not displace native species through competition for resources, but rather affects them non-trophically through its litter. Moreover, because $T . \times$ glauca plants were taller when grown with their own litter, we suggest that this invader may produce positive feedbacks and change the environment in ways that benefit itself and may promote its own invasion.
\end{abstract}

Key words: diversity; Great Lakes wetlands; litter; mechanisms of invasion; positive feedbacks; Typha $\times$ glauca.

\section{INTRODUCTION}

Invaded systems are often associated with a change in ecosystem processes and a decline in native species abundance and/or diversity (D'Antonio and Vitousek 1992, Hobbs and Huenneke 1992, Galatowitsch et al. 1999, Zedler and Kercher 2004, MacDougall and Turkington 2005, Kercher et al. 2007). Managing invaded systems and mitigating negative impacts requires an understanding of the mechanisms driving these relationships. However, because many different causal pathways may link invasion, environmental change, and native decline, it is unlikely that any one set of mechanisms operates in all systems and therefore that management recommendations are similar across systems. Instead, we need to understand the range of causal pathways and, eventually, the conditions under which different mechanisms are more or less important. Fig. 1 describes a set of conceptual models for the linkages between invasion, ecosystem changes, and native decline based on the combination of the initial driver of the

Manuscript received 7 March 2008; revised 16 June 2008; accepted 27 June 2008. Corresponding Editor: J. C. Callaway.

${ }^{1}$ E-mail: ecfarrer@umich.edu environmental change and the mechanism behind the native species decline.

Environmental change can be initiated by humans or by the invader itself. In human-directed models (Fig. 1, top row), changes in ecosystem processes are caused anthropogenically, for example by alteration of disturbance regimes (e.g., fire suppression), biogeochemistry (e.g., eutrophication), or hydrology (e.g., wetland draining). This change in environment allows the invader to establish and spread because it may create a temporary resource opportunity (Davis et al. 2000) or because the invader is well adapted to these new conditions (Dukes and Mooney 1999). In invaderdirected models (Fig. 1, bottom row), the invader establishes at a site due to chance or propagule pressure and, because of physiological differences from the native vegetation, it changes ecosystem processes such as nutrient cycling (Ehrenfeld 2003) or disturbance regime (Mack and D'Antonio 1998).

Independently of the cause of environmental change, native species abundance, diversity, or composition may decline when associated with invasions due to three different reasons. (1) Native species may decline due to the human-induced changes to the environment, if they are not adapted to the human-induced selection regime 


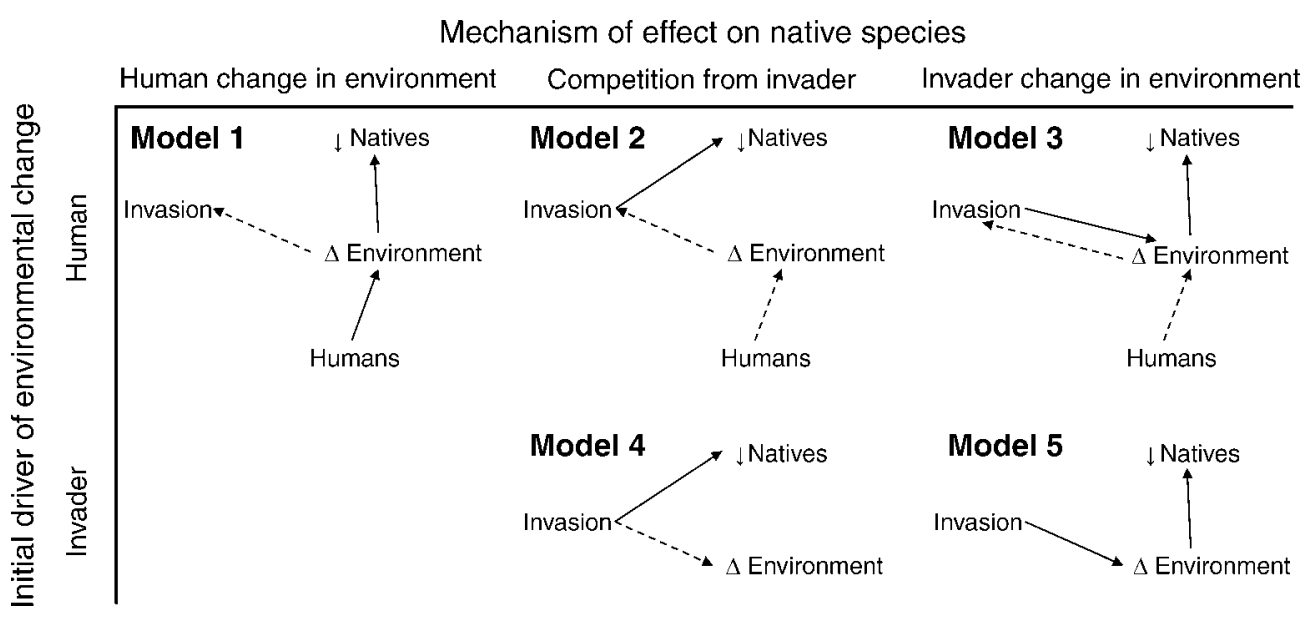

FIG. 1. Five models of causal relationships explaining the common pattern of invasion, environmental change, and decline in native species. The models are organized based on the initial driver of environmental change (left axis), and the mechanism of effect on native species (horizontal axis). Either humans (models 1-3) or the invader (models 4-5) are the initial drivers of the environmental change. Native species decline due to human changes in environment (model 1), resource competition from the invader (models 2, 4), or invader changes in the environment (non-trophic effects of the invader; models 3, 5). The solid lines indicate the pathway of native species decline, while the dashed lines represent concomitant changes with no direct effect on native species. None of the models are mutually exclusive, and multiple causal pathways could contribute to the observed field pattern.

(Fig. 1, column 1; Byers 2002, Didham et al. 2005, MacDougall and Turkington 2005). This is the same as the "passenger model" of MacDougall and Turkington (2005) in which the invader does not cause native decline at all but is just a passenger in a system already undergoing environmental change. (2) Native species may decline due to competitive pressure from the new invader (Fig. 1, column 2). When competition is combined with human-directed environmental change (model 2), this represents the "driver" model of MacDougall and Turkington (2005), in which humans change the environment causing a shift in competitive ability such that the invader is now more competitive than the natives. (3) Lastly, the invader might change the environment in such a way that native species are no longer competitive or able to persist at all (Fig. 1, column 3). For example, if the invader's litter reduces light levels or increases sedimentation or anoxia, these non-trophic (non-uptake) effects may inhibit native species.

These five models shown in Fig. 1, differentiated by the combination of the cause of environmental change and the mechanism of native decline, are not mutually exclusive, and the relative importance of each pathway may depend on site conditions (e.g., Scott et al. 2001, Ehrenfeld 2003). Despite this complexity, determining the cause and effect relationships among these factors is essential for designing effective management strategies, including conservation and remediation. Knowing the extent to which humans vs. invaders are the cause of environmental change is important for determining if and how human processes should be regulated. Determining the cause of the decline in native species is important for identifying remediation methods. For example, models 2 and 4 suggest only invader removal is necessary to promote the regrowth of native plants, while models 1, 3, and 5 suggest that underlying environmental changes must be addressed before the conditions are suitable again for native species (Suding et al. 2004).

In wetland habitats, the most important environmental change associated with invasion and diversity decline is often eutrophication (Galatowitsch et al. 1999, Childers et al. 2003, Zedler and Kercher 2004). Both humans and invaders could potentially initiate this pattern and cause the increase in nutrients. Anthropogenic nutrient input is often assumed to be the cause of elevated nutrient levels and is reasonable in cases where input is known (Davis and Ogden 1994, Drexler and Bedford 2002). However, it is well documented that invasives (Ehrenfeld 2003, Levine et al. 2003), and plant species more generally (Eviner and Chapin 2003), can influence ecosystem processes such as nutrient cycling due to differences in physiology and morphology. For example, invasive wetland plants can stimulate microbial processes via root exudates or through oxygenation of the rhizosphere (Windham and Ehrenfeld 2003). Invasive plants can also increase $\mathrm{N}$ cycling through their litter production. Litter with low $\mathrm{C}: \mathrm{N}$ or low lignin can increase the rate of microbial mineralization because it is easily decomposed and $\mathrm{N}$ is quickly made available (Hobbie 1992). Invasives that produce large quantities of litter may also increase $\mathrm{N}$ supply in a wetland, because the litter can act as a carbon source for microbes and can retain $\mathrm{N}$ in the system in the organic $\mathrm{N}$ pool (Bowden 1987).

Eutrophication and invasion in wetlands are often associated with a decline in native species abundance or diversity or a change in species composition (Meyerson et al. 2000, Kercher et al. 2007). However, this 
relationship is not always quantified (Galatowitsch et al. 1999), and unexpected positive relationships have also been found (Hager and Vinebrooke 2004). Moreover, rarely is the mechanism of species decline investigated (Levine et al. 2003), even though the three causes for the decline in native species in Fig. 1 are all plausible. A decline in diversity may result solely from the native community response to elevated nutrients, due to dominance by a particularly productive native species (Green and Galatowitsch 2002). More likely, resource competition from the invader can cause decline of native species. Due to high growth rates and high productivity, invasives such as Typha spp., Phragmites australis, and Phalaris arundinacea are competitive in high nutrient environments and can take advantage of the elevated resources (Galatowitsch et al. 1999, Zedler and Kercher 2004). Numerous fertilization experiments have confirmed this invader-growth response coupled with native-species decline (Newman et al. 1996, Green and Galatowitsch 2001, 2002, Svengsouk and Mitsch 2001, Woo and Zedler 2002, Minchinton and Bertness 2003, Rickey and Anderson 2004, Kercher et al. 2007). Thus resource competition from invaders for nutrients or light is a highly probable mechanism for observed declines in native species. Lastly, a decline in natives may also result from non-trophic modification of the environment by the invasive species. Large stands of litter often accumulate when very productive invaders occupy eutrophied environments, and this litter reduces light levels and physically obstructs growth of native species (Hager 2004). These mechanisms of native decline are not mutually exclusive; both resource competition and litter accumulation can concurrently inhibit native species (Lenssen et al. 2000, Minchinton et al. 2006).

The associations among invasion, ecosystem properties, and native plant communities have been well documented. However, the majority of the ecosystemprocess studies have been non-manipulative surveys; thus they cannot distinguish the direction of causality in invader-environment relationships, nor can they separate the mechanisms behind the associations they see due to the many covarying variables. Likewise, most plant community studies have not separated trophic and nontrophic effects of the invader, and cannot distinguish between strict competitive superiority of the invader or environmental modifications due to litter production.

In this paper, we quantify the field association of invasion, eutrophication, and decline in native species in Great Lakes coastal marshes invaded by Typha $\times$ glauca Godr. (hybrid cattail). We also test whether $T . \times$ glauca can be the initial driver of environmental change (does row 2, Invader, in Fig. 1 occur?) and whether $T$. $\times$ glauca affects native species through competition (does column 2, Competition from invader, occur?) and/or non-trophic interactions (does column 3, Invader change in environment, occur?). We assessed the contributions of these models with a transplant experiment using factorial combinations of live $T . \times$ glauca individuals with or without the addition of $T . \times$ glauca litter. Invaderdirected models in Fig. 1 (row 2, Invader) predict that $T$. $\times$ glauca should increase soil nutrients either via its live plants or its litter. If resource competition (column 2, Competition from invader) is responsible for native decline, then the live $T . \times$ glauca treatment is predicted to cause both a decrease in some resource (either nutrients or light) and a decline in natives. If nontrophic effects (column 3, Invader change in environment) are responsible for native decline, then the litter treatment would be predicted to cause both a decrease in some resource and a decline in natives (i.e., a decrease in abundance or diversity or a change in species composition). Because we tested whether a particular model (or group of models) could occur, and because the models are not mutually exclusive, our approach can support the existence of a contribution from a model but does not reject contribution from other models. Thus this paper is a first, but critical, step in understanding and measuring the many cause-effect relationships in an invasive system in order to begin to build generalizations about conditions under which different causal pathways are important. Because $T . \times$ glauca is an important invasive in many wetland systems, these results also have direct management implications.

\section{Methods \\ Study species}

Typha $\times$ glauca Godr. (hybrid cattail) is an aggressive wetland invasive in North America (Galatowitsch et al. 1999). It is the hybrid between Typha latifolia L. and Typha angustifolia L. Typha latifolia, broadleaf cattail, is native to temperate North America and Eurasia and has a broad distribution on both continents (Grace and Harrison 1986). Typha angustifolia, narrow-leaved cattail, is not native to the midwestern United States and was most likely introduced from Europe to the east coast in the early 19th century (Stuckey and Salamon 1987; but see Pederson et al. 2005). It was restricted to salt marshes of the Atlantic coast until the 1880s, was first reported in Michigan in 1900, and now occupies much of the northeast habitat of T. latifolia (Stuckey and Salamon 1987, Galatowitsch et al. 1999). These two parent species commonly co-occur in wetlands and readily hybridize; the distribution of $T . \times$ glauca follows that of T. angustifolia as it encounters and hybridizes with T. latifolia (Grace and Harrison 1986, Stuckey and Salamon 1987, Galatowitsch et al. 1999). Although the genetic status of the hybrid is still uncertain, populations examined so far are composed mostly of $\mathrm{F}_{1}$ hybrids (Kuehn et al. 1999; A. A. Snow, T. Fér, R. Wildova, and D. E. Goldberg, unpublished data). Typha $\times$ glauca appears to exhibit hybrid vigor: it is taller than either parent species, is tolerant of prolonged flooding, drainage, and salinity, and is often argued to be able to outcompete them (Smith 1987, Waters and Shay 1990, 1992, Galatowitsch et al. 1999). For field identification, we used the ratio leaf width: leaf length 
and spike gap length, which were selected by discriminant function analysis to have the best fit with genetically identified samples (by random amplified polymorphic DNA [RAPD] and microsatellite analysis) of the hybrid and the two parent species (A. A. Snow, T. Fér, R. Wildova, and D. E. Goldberg, unpublished data).

\section{Coastal wetlands survey}

Three Great Lakes coastal marshes in northern Michigan were chosen to quantify the relationships among $T$. $\times$ glauca invasion, nutrient availability, and the native community: Cheboygan marsh on Lake Huron ( $\left.45^{\circ} 39^{\prime} 31^{\prime \prime} \mathrm{N}, 84^{\circ} 28^{\prime} 16^{\prime \prime} \mathrm{W}\right)$, Pt. la Barbe marsh in the Straits of Mackinac $\left(45^{\circ} 50^{\prime} 20^{\prime \prime} \mathrm{N}, 84^{\circ} 45^{\prime} 24^{\prime \prime} \mathrm{W}\right)$, and Cecil Bay marsh on Lake Michigan $\left(45^{\circ} 44^{\prime} 48^{\prime \prime} \mathrm{N}\right.$, $\left.84^{\circ} 48^{\prime} 02^{\prime \prime} \mathrm{W}\right)$. Each site contained both an area of native vegetation and a considerable stand of $T . \times$ glauca .

In 2003, one transect was run through each marsh (ranging from 200 to $285 \mathrm{~m}$ ), extending perpendicular to the shoreline. A $1-\mathrm{m}^{2}$ plot was set up approximately every $20 \mathrm{~m}$ along the transect. In each plot, stems of each species of vascular plant were counted (seedlings excluded) and percent cover of litter/standing dead was estimated. Some $T$. angustifolia was mixed in with the $T$. $\times$ glauca at all of the sites; T. latifolia was very rare at all of the sites and not present in or near any of the transects. All other species in the plots were native, with a few exceptions present at low abundance and in $<5 \%$ of the plots: Poa compressa and possibly exotic genotypes of Phalaris arundinacea and Phragmites australis. Species richness of the native (non-Typha) species was tallied, and Shannon-Wiener diversity was calculated as $H=\Sigma\left(-p_{i} \ln p_{i}\right)$, where $p_{i}$ is the proportion of total native stems of species $i$. For each plot, litter depth, soil temperature at $10 \mathrm{~cm}$, and water depth were measured, and a single soil sample (10 cm depth) was collected. Great Lakes water levels are very dynamic so water depth measurements only indicate relative depths within a site. Soil samples were dried $\left(70^{\circ} \mathrm{C}\right)$ and sieved (2 mm), and extractable $\mathrm{PO}_{4}{ }^{3-}, \mathrm{NO}_{3}{ }^{-}, \mathrm{NH}_{4}{ }^{+}$, and soil organic matter (SOM) were quantified using the analytical methods described below for the transplant experiment. Oven-dried soil was used for this analysis; thus the results serve as a general index of relative amounts of inorganic soil $\mathrm{N}$ and $\mathrm{P}$ within and among the transects, but cannot be used for comparison with absolute amounts based on wet soil extraction in the following transplant experiment or other studies due to the transformations that occur during the drying process.

\section{Statistical analyses}

The sample size for each site was small $(n=10,12,15$ plots), so data from the three sites were pooled and analyzed together (except for the species composition analysis described next). Because many of the environmental variables covaried, their relationships were investigated using principal components analysis
(PCA) with Canoco 4.0 (ter Braak 1987, ter Braak and Smilauer 1998). Variables that appeared to be nonlinearly related were analyzed pairwise with quadratic regressions (SPSS 11; SPSS, Chicago, Illinois, USA).

Patterns between native species composition and the environmental variables (including $T . \times$ glauca) were tested using ordination methods with Canoco 4.0. Species stem densities were log-transformed to counteract skewness. Species present in $<5 \%$ of the plots (doubletons and singletons) were omitted from the analysis, because they do not contribute greatly to species composition and standardization with two occurrences can bias results. A preliminary detrended components analysis (DCA; Hill and Gauch [1980]) was performed to determine if linear or nonlinear (unimodal) methods were most appropriate. The length of the main floristic gradient in the DCA was 4.090 standard deviations, so a nonlinear canonical correspondence analysis (CCA) was chosen because nonlinear responses are expected along gradients of length $>4$. In the CCA, site was used as a covariable. Due to the large number of environmental variables (eight), forward selection was used to select only the variables that contributed significantly $(P<0.05)$ to explaining variation in species composition with statistical testing by unrestricted Monte Carlo permutation tests for each added variable (ter Braak 1990, ter Braak and Verdonschot 1995). The unique contribution of each selected environmental variable was determined by performing a CCA with all other environmental variables and site as covariables; statistical significance of this was tested using Monte Carlo permutation tests within Canoco, with 499 permutations within site, and significance based on the overall (trace) statistic.

\section{Transplant experiment site and design}

The transplant experiment was conducted in Cheboygan marsh. The native vegetation at this site consists mainly of $\sim 15$ species of rushes (Juncaceae) and sedges (Cyperaceae) as well as a few species of wetland grasses and forbs. Typha $\times$ glauca is thought to have invaded the marsh 30-40 years ago and now occupies approximately two-thirds of the marsh area (N. C. Tuchman, P. Geddes, D. Larkin, R. Wildova, K. J. Jankowski, and D. E. Goldberg, unpublished manuscript).

In July 2004, live $T . \times$ glauca plants and $T . \times$ glauca litter were transplanted in a factorial design into $1-\mathrm{m}^{2}$ plots in 10 replicate blocks throughout the uninvaded area of the marsh. These four treatments will be referred to as the following: no-live-no-litter, litter only, live only, and live + litter. Live $T . \times$ glauca plants were collected from 10 locations, at least $20 \mathrm{~m}$ apart, throughout the dense $T . \times$ glauca stand to attempt to maximize genetic diversity, so that results can be better generalized to $T$. $\times$ glauca as a taxon. Because $T$. $\times$ glauca grows rapidly, only 10 stems (one-third the density of the dense $T . \times$ glauca stand in the marsh) were planted per plot; by the next growing season when the 
data reported here were collected (2005), mean $T$. $\times$ glauca density had increased to $25 \mathrm{stems} / \mathrm{m}^{2}$. Surface $T$. $\times$ glauca litter was collected at the same locations, mixed, and the equivalent of $2 \mathrm{~kg}$ dry mass (the mean quantity of aboveground litter in dense $T$. $\times$ glauca stands) was transplanted per plot. Litter was held in place from movement by water by pond netting (mesh size $\sim 1 \mathrm{~cm}$ ), which was kept on the litter plots throughout the duration of the experiment. Typha litter is typically a mass of senescent stems still rooted in place but bent horizontally and lying on the surface; thus, the net helps mimic this relative litter immobility; in general, free-floating litter and litter removal from the marsh due to water movement by seiches is highly uncommon (E. C. Farrer and D. E. Goldberg, personal observation). At the end of the 2004 growing season, T. $\times$ glauca litter produced by the live only and the live + litter plots was clipped, divided equally, and placed under the netting in the litter only and live + litter plots.

Prior to transplanting, all treatment plots were clipped and cleared of native plants and native litter so that the stems of native plants would not be crushed in the litter treatment, potentially causing an influx of nutrients to the soil. For this reason, an additional control plot (a pretreatment clipping control) was also established in each block, to test the effects of clipping of all treatment plots. The amount of litter removed from native plots $\left(190 \mathrm{~g} / \mathrm{m}^{2}\right)$ was only $\sim 10 \%$ of the amount of cattail litter added $\left(2000 \mathrm{~g} / \mathrm{m}^{2}\right)$, so it is unlikely that its removal had substantial impact on the results.

\section{Environmental measurements}

Available $\mathrm{NH}_{4}{ }^{+}$and $\mathrm{NO}_{3}{ }^{-}$and net $\mathrm{N}$ mineralization measurements were taken in each plot in June and August 2005. N mineralization was measured using 1 month in situ buried bag incubations. On the first of each month, two soil cores $(5 \mathrm{~cm}$ diameter $\times 10 \mathrm{~cm}$ depth) were taken from each plot and placed in a polyethylene bag; one bag was put on ice and transported back to the laboratory for processing, and the other was returned to the soil. Soil-incubated samples were retrieved from the field after 28 days. In the lab, soils were immediately sieved $(2 \mathrm{~mm})$ and a $10-\mathrm{g}$ subsample was extracted for 1 hour with $40 \mathrm{~mL}$ of 2 $\mathrm{mol} / \mathrm{L} \mathrm{KCl}$. Extracts were filtered (Whatman $\mathrm{GF} / \mathrm{F}$; Whatman, Florham Park, New Jersey, USA) and frozen until colorimetric analysis for $\mathrm{NH}_{4}^{+}$and $\mathrm{NO}_{3}^{-}$with a Bran Luebbe autoanalyzer 3 (Hamburg, Germany; Eaton et al. 1995). A 10-g subsample was dried at $105^{\circ} \mathrm{C}$ for wet: dry ratio, and SOM was measured by combusting the dried sample for 5 hours at $500^{\circ} \mathrm{C}$. Bulk density ( $\mathrm{g}$ soil $/ \mathrm{mL}$ ) in each plot was determined by subtracting the mass and volume of the coarse fraction from the total core mass and volume for the June incubated soil cores. There were only slight block differences in bulk density, so available nutrients and mineralization rates were calculated on an aerial basis using the overall mean bulk density $(1.34 \mathrm{~g} / \mathrm{mL})$. Nitrate concentrations for all initial samples were 0 or negligible, as is often the case in anaerobic wetland soils (Bowden 1987), so $\mathrm{NH}_{4}^{+}-\mathrm{N}\left(\mathrm{mg} \mathrm{N} / \mathrm{m}^{2}\right)$ in initial soil cores was used as a measure of available $\mathrm{N}$. N mineralization $\left(\mathrm{mg} \mathrm{N} \cdot \mathrm{m}^{-2} \cdot \mathrm{d}^{-1}\right.$ ) was calculated as the increase in $\mathrm{NH}_{4}{ }^{+}-\mathrm{N}$ plus $\mathrm{NO}_{3}{ }^{-}-\mathrm{N}$ over the 28 days.

Available phosphorus was measured in August 2005 by extracting a 10-g subsample from the August initial soil core with $40 \mathrm{~mL}$ Troug's solution ( $1 \mathrm{mmol} / \mathrm{L} \mathrm{H}_{2} \mathrm{SO}_{4}$ $\left.+\left(\mathrm{NH}_{4}\right)_{2} \mathrm{SO}_{4}, \mathrm{pH}=3\right)$ for 1 hour. The extract was centrifuged, filtered $(0.45 \mu \mathrm{m})$, and refrigerated $\left(4^{\circ} \mathrm{C}\right)$ until colorimetric analysis on a Bran Luebbe autoanalyzer 3 (Eaton et al. 1995).

Light penetration through the vegetation and litter was measured in late July 2005 as photon flux $\left(\mu \mathrm{mol} \cdot \mathrm{s}^{-1} \cdot \mathrm{m}^{-2}\right)$ at the soil surface divided by total photon flux above the vegetation using a LI-COR quantum sensor LI-250A (LI-COR, Lincoln, Nebraska, USA). Light at the soil surface was measured at a point location by averaging over a 15 second period. Two point locations were measured per plot and these two measurements were averaged. All measurements were taken within one hour of solar noon.

Water depth and soil temperature $(5 \mathrm{~cm}$ below the surface) was measured in each plot twice in June and twice in August. Temperature measurements were taken within a 1.5-hour block of time starting $\sim 45$ minutes after solar noon because after that, soil temperature no longer warms substantially. The water and temperature measurements were averaged by month.

\section{Plant measurements}

Plant community composition in the four factorial experimental treatments was quantified in mid July 2005 by stem counts of rooted vascular plants. ShannonWeiner diversity $(H)$ was calculated for each plot using stem densities of native species, as previously described in the survey. Similar to the survey, almost all species observed during the experiment (other than the transplanted $T . \times$ glauca) were native. Exceptions included Agrostis gigantea (common) and possible exotic genotypes of Agrostis stolonifera and Phalaris arundinacea (both present in $<5 \%$ of plots). The maximum height of the native vegetation and of $T . \times$ glauca was measured in all plots in late July 2005.

The control plots for the pretreatment clipping were not censused for stem densities due to time constraints; because the majority of the species are clonal and resprout from rhizomes, clipping is not likely to have a large effect on species richness and relative abundance.

\section{Statistical analysis}

The effect of treatment (live, litter, and live $\times$ litter interaction) and block on available $\mathrm{NH}_{4}{ }^{+}$and $\mathrm{N}$ mineralization was analyzed with repeated-measures ANOVA (SPSS 11) because data were taken in both June and August. Treatment and block effects on environmental variables that were measured once 


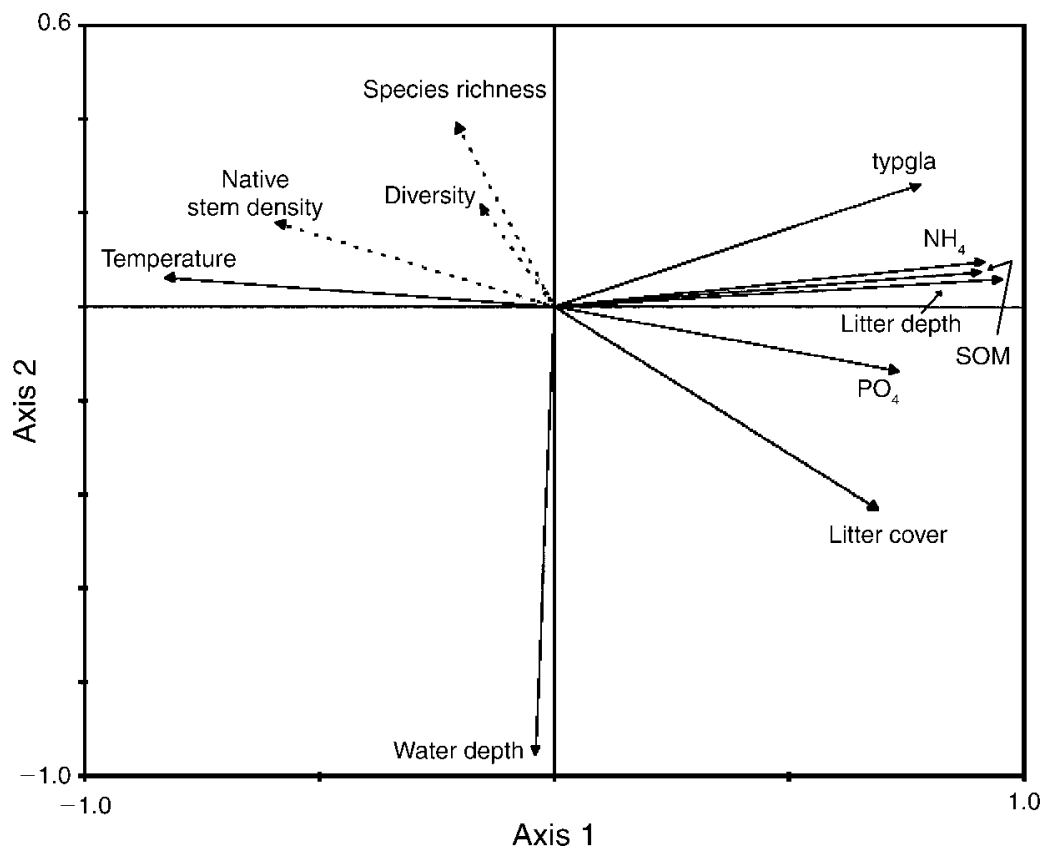

FIG. 2. Principle components analysis (PCA) ordination of environmental variables (solid lines) including T. $\times$ glauca density (typgla) from the field survey. Native stem density, species richness, and diversity were added as supplementary variables (dashed lines), so that they do not influence the ordination, but so that their correlations with the environmental variables can be visualized. Axis 1 explains $60.8 \%$ of all variation in environmental variables, and axis 2 explains an additional 15.1\%. SOM is soil organic matter.

$\left(\mathrm{PO}_{4}{ }^{3-}, \mathrm{SOM}\right.$, light $)$ and the native community measurements (stem density, species diversity, native vegetation max height) were analyzed with ANOVA (SPSS 11). Interaction terms including blocks in the ANOVAs were not investigated due to limited degrees of freedom ( $n=10$ plots per treatment combination) and because blocks did not appear to respond qualitatively differently to the different treatments.

The effect of pretreatment clipping was analyzed with a separate repeated-measures or regular ANOVA in which the no-litter-no-live treatment plot (the control for the factorial experiment) was compared to the pretreatment clipping control plot.

The effect of the experimental treatments on species composition of non-Typha spp. was analyzed using Canoco 4.0. Methods were identical to those used for the field survey CCA with the following exceptions: (1) forward selection was not used because there were only three treatment variables and (2) block was used as a covariable. In general, in doing a CCA, species abundances are standardized by species and by plot, which converts abundances to relative abundances. Thus, CCA tests whether species relative abundances are differentially affected by the treatments.

To determine whether experimental results were similar to field observations, the species responses to litter from the 2005 transplant experiment were compared to those from the 2003 survey. The Pearson correlation coefficient was calculated and a one-tailed significance test was done to determine if species scores along the litter axis from the survey CCA ordination were positively correlated with those from the experiment ordination.

\section{RESULTS}

\section{Coastal wetlands survey}

The environmental variables indicative of high nutrient conditions and low light $\left(\mathrm{NH}_{4}{ }^{+}, \mathrm{PO}_{4}{ }^{3-}, \mathrm{SOM}\right.$, litter depth, litter percent cover, soil temperature) covaried strongly with each other as reflected in axis 1 in the PCA (Fig. 2). Axis 1 explains $60.8 \%$ of the variance in environmental variables. Water depth varied only with axis 2 , which explains $15.1 \%$ of the variance, thus it was not correlated with any of the above variables (Fig. 2).

Live $T . \times$ glauca density was associated with high nutrients $\left(\mathrm{NH}_{4}{ }^{+}, \mathrm{PO}_{4}{ }^{3-}, \mathrm{SOM}\right)$ and low light environments (high litter depth, litter percent cover, low soil temperature) because it also loaded positively on axis 1 of the PCA (Fig. 2). It was not related to water depth (Fig. 2). Interestingly, despite the overall positive correlations between $T$. $\times$ glauca density and high nutrients, $T . \times$ glauca stems were not restricted to high nutrient locations; rather they were also present in low nutrient microsites and were also abundant in one of the sites which was fairly oligotrophic overall (Fig. 3).

The stem density of the native community was negatively associated with $T$. $\times$ glauca density, litter depth, and the covarying environmental variables $\left(\mathrm{NH}_{4}{ }^{+}, \mathrm{PO}_{4}{ }^{3-}, \mathrm{SOM}\right.$, litter percent cover, soil temperature), because it loaded negatively on axis 1 of the PCA 


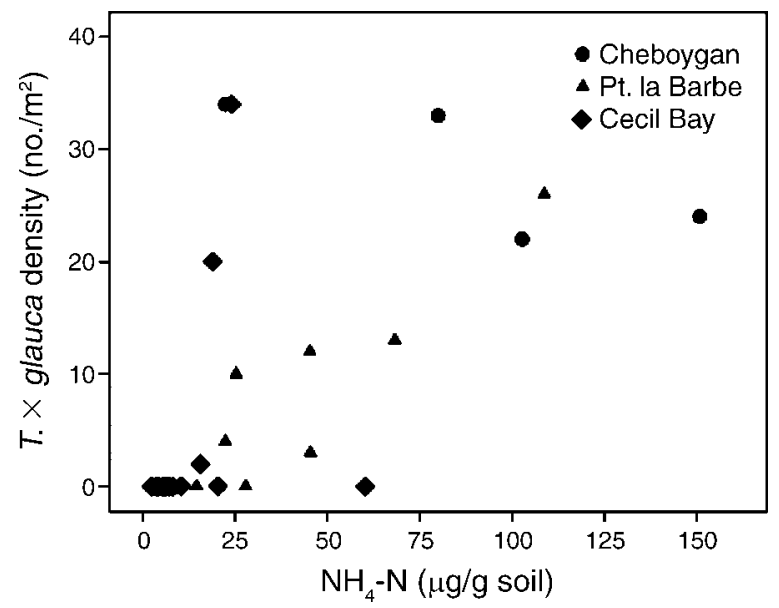

FIG. 3. Typha $\times$ glauca density and extractable nitrogen levels in the field survey. Note that T. $\times$ glauca is not restricted to high nutrient microsites and is abundant even in a site that is fairly oligotrophic overall (Cecil Bay).

(Fig. 2). Shannon-Weiner diversity was negatively associated with litter percent cover and water depth on the PCA but was not associated with live $T . \times$ glauca density or any of the other environmental variables as shown by their orthogonal vectors in the PCA (Fig. 2). However, diversity was strongly related nonlinearly to litter depth $\left(R^{2}=0.557, P<0.001\right)$, in a hump-shaped relationship with highest diversity at intermediate litter depths (Fig. 4). Weaker nonlinear (hump-shaped) relationships were also found between diversity and soil $\mathrm{NH}_{4}{ }^{+}\left(R^{2}=0.237, P=0.010\right)$ and $\operatorname{SOM}\left(R^{2}=0.228, P=\right.$ 0.012 ; Fig. 4). Interestingly, diversity was not nonlinearly related to $T . \times$ glauca stem density $\left(R^{2}=0.014\right.$, $P=0.79$ ). Species richness showed correlation patterns similar to Shannon-Weiner diversity (data not shown).

The results from forward selection in the CCA indicate that four of the eight environmental variables explain a significant and substantial $(28.0 \%)$ portion of the variance in species composition: soil temperature, water depth, litter depth, and $\mathrm{PO}_{4}{ }^{3-}$ (Fig. 5). Notably, density of live $T . \times$ glauca stems was not in this group. Site effects (differences among the three marshes) explained $14.2 \%$ of the variance. The first axis $(13.9 \%$ of the variance) is a gradient of increasing litter and nutrient levels and decreasing light levels. Many of the rush (Juncaceae) and sedge, bulrush, and spikerush (Cyperaceae) species that are typical wetland dominants were more common at the low-litter, low-nutrient, highlight end of the gradient, including Juncus spp., Eleocharis spp., Schoenoplectus spp., and Carex viridula. Grasses and forbs predominate at the high-litter, highnutrient, low-light end of the gradient, with the exception of four Carex species (Cyperaceae), which were positively associated with this axis. These species are all fairly productive and generate a lot of litter themselves.

\section{Transplant experiment}

Effects of $\mathrm{T} . \times$ glauca on the abiotic environment.-All significant treatment effects on the abiotic environment were brought about by litter and not by the live $T$. $\times$ glauca transplants (Table 1, Fig. 6). Addition of $T$. $\times$
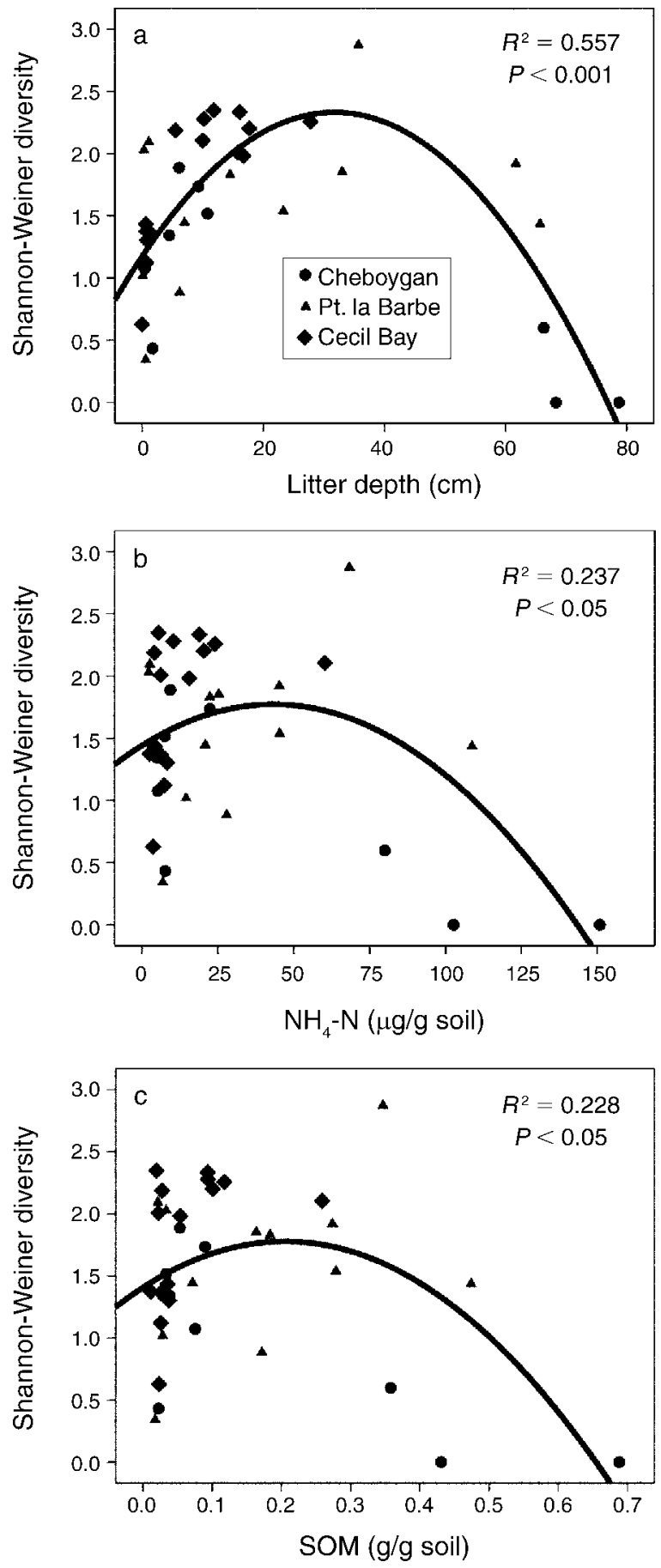

FIG. 4. Significant nonlinear relationships between Shannon-Weiner diversity and environmental variables in the field survey. 


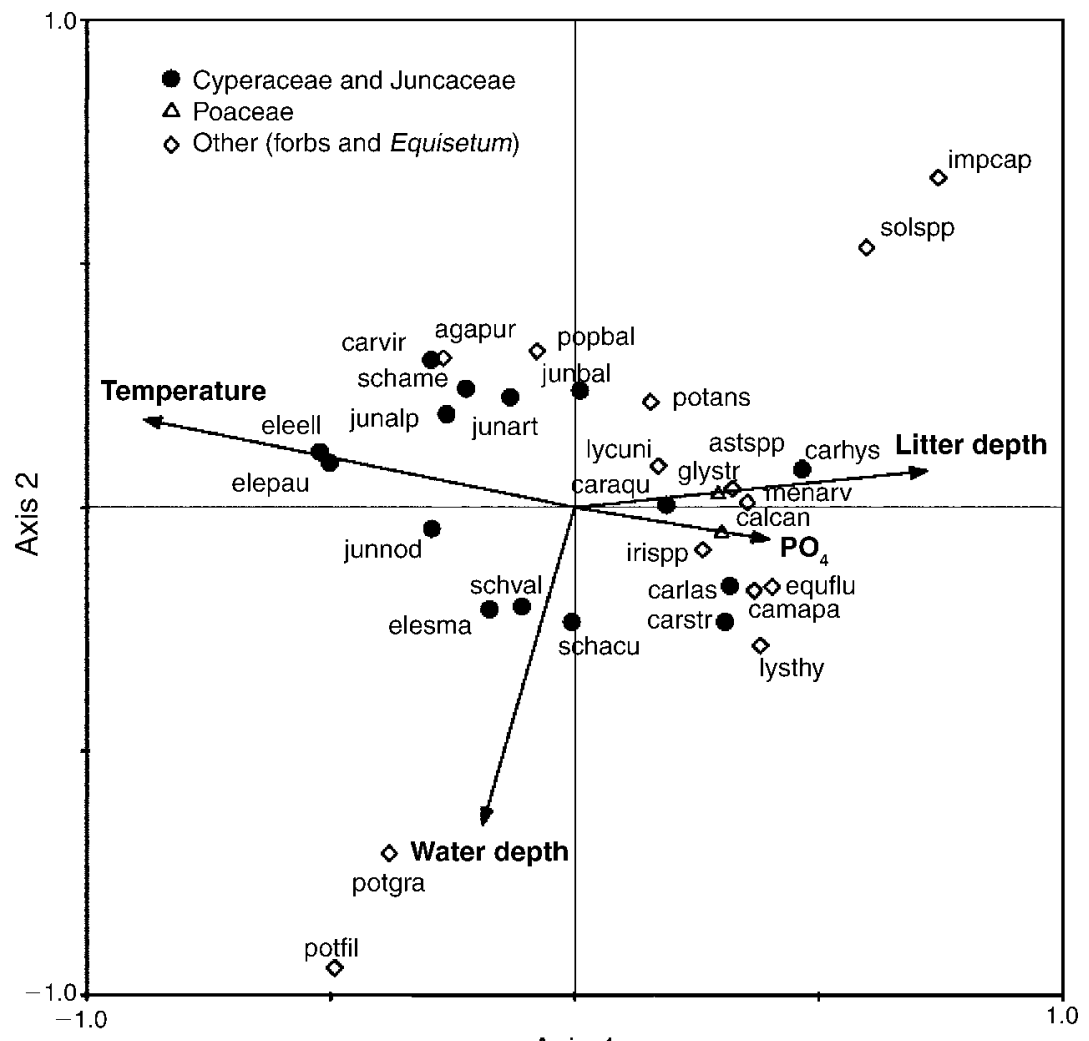

Axis 1

FIG. 5. Biplot of environmental variables and species scores from the canonical correspondence analysis (CCA) ordination of native species densities from the field survey. Axes 1 and 2 explain $13.9 \%$ and $8.4 \%$ of the total variation, respectively. The four environmental variables together explain $28.0 \%$ of the total floristic variation, and site explains $14.2 \%$. Significant environmental variables were temperature (8.7\% of the floristic variation), water depth $(8.0 \%)$, litter depth $(4.0 \%)$, and $\mathrm{PO}_{4}(2.9 \%)$; nonsignificant variables were live $T$. $\times$ glauca density, litter percent cover, $\mathrm{NH}_{4}$, and soil organic matter $(\mathrm{SOM})$. The most important (in fit and weight) 31 of 45 species are shown in this figure. Abbreviations for species names are the first three letters of the genus and species: agapur, Agalinis purpurea; astspp, Aster spp.; calcan, Calamagrostis canadensis; camapa, Campanula aparinoides; caraqu, Carex aquatilis; carhys, Carex hystericina; carlas, Carex lasiocarpa; carstr, Carex stricta; carvir, Carex viridula; eleell, Eleocharis elliptica; elepau, Eleocharis pauciflora; elesma, Eleocharis smallii; equflu, Equisetum fluviatile; glystr, Glyceria striata; impcap, Impatiens capensis; irispp, Iris spp.; junalp, Juncus alpinus; junart, Juncus articulatus; junbal, Juncus balticus; junnod, Juncus nodosus; lycuni, Lycopus uniflorus; lysthy, Lysimachia thyrsiflora; menarv, Mentha arvensis; popbal, Populus balsamifera; potfil, Potamogeton filiformis; potgra, Potamogeton gramineus; potans, Potentilla anserina; schacu, Schoenoplectus acutus; schame, Schoenoplectus americanus; schval, Schoenoplectus validus; solspp, Solidago spp.

TABLE 1. Effect of litter and live Typha $\times$ glauca treatments on environmental and community characteristics.

\begin{tabular}{lcccccc}
\hline \hline \multicolumn{1}{c}{ Variable } & $\begin{array}{c}\text { Error } \\
\mathrm{df}\end{array}$ & $\begin{array}{c}\text { Litter } \\
(\mathrm{df}=1)\end{array}$ & $\begin{array}{c}\text { Live Typha } \\
(\mathrm{df}=1)\end{array}$ & $\begin{array}{c}\text { Litter } \times \text { live } \\
(\mathrm{df}=1)\end{array}$ & $\begin{array}{c}\text { Block } \\
(\mathrm{df}=9)\end{array}$ & $\begin{array}{c}\text { Time } \\
(\mathrm{df}=1)\end{array}$ \\
\hline $\mathrm{NH}_{4}^{+}$ & 27 & $7.13^{*}$ & 0.29 & 1.56 & $3.36^{* * *}$ \\
$\mathrm{Nmineralization}^{3-}$ & 27 & $59.66^{* * *}$ & 0.67 & 0.85 & $5.79^{* * *}$ & 4.282 \\
$\mathrm{PO}_{4}$ & 27 & 2.06 & 0.07 & 0.68 & $4.30^{* *}$ \\
Soil organic matter & 27 & 1.70 & 0.34 & 1.29 & $5.27^{* * *}$ \\
Light & 27 & $426.15^{* * *}$ & 1.59 & 1.54 & 1.33 \\
Stem density & 27 & $20.96^{* * *}$ & 0.70 & 0.09 & $4.08^{* *}$ \\
Species diversity & 27 & $4.69^{*}$ & 0.65 & 0.54 & $6.48^{* * *}$ \\
Native vegetation max height & 27 & $5.30^{*}$ & 1.41 & 2.15 & $11.97^{* * *}$ \\
Typha density & 9 & 0.85 & & & 1.05 \\
Typha max height & 9 & $16.19^{* *}$ & & & 1.17
\end{tabular}

Notes: Data shown are $F$ statistics from ANOVAs with significance indicated by asterisks $(* * * P<0.001, * * P<0.01, * P<$ 0.05 ). $\mathrm{NH}_{4}{ }^{+}$and $\mathrm{N}$ mineralization were measured in June and August and tested with repeated measures ANOVAs. Interactions of the treatments and block with time are not shown, but are mentioned in the text if significant. All other variables were tested with ANOVA. The rows "Typha density" and "Typha max height" are measurements of live Typha plants; therefore, they were only measured in the 20 plots with live cattails (i.e., the live only and live + litter plots), and litter is the only main effect tested. 

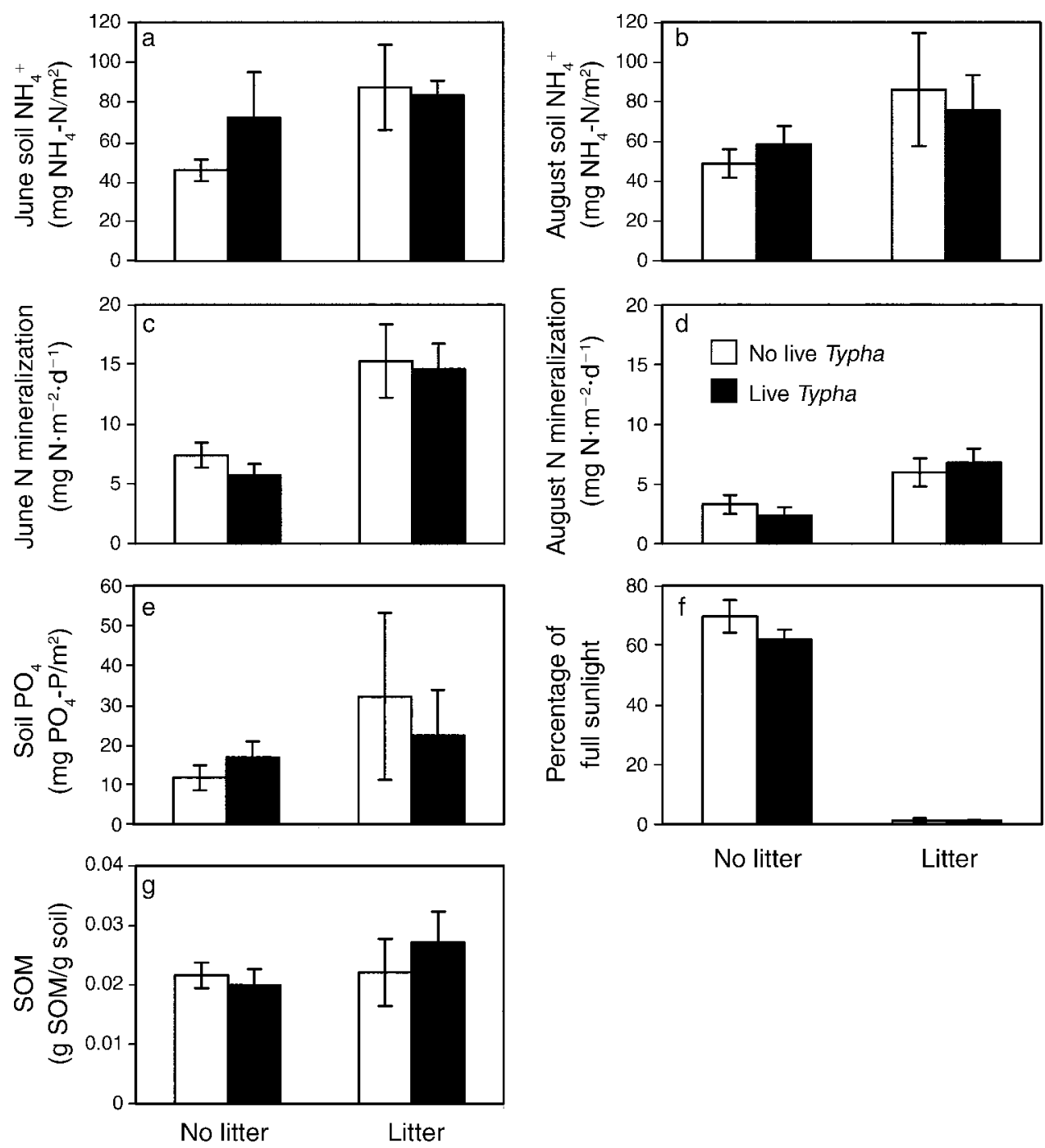

FIG. 6. (a, b) Effect of transplanted T. $\times$ glauca plants and litter on soil $\mathrm{NH}_{4}^{+}$pools in (a) June and (b) August; (c, d) $\mathrm{N}$ mineralization in (c) June and (d) August; (e) soil $\mathrm{PO}_{4}{ }^{3-}$ pools; (f) light; and (g) soil organic matter (SOM). Numbers are means \pm $\mathrm{SE}(n=10$ replicates). For ANOVA results see Table 1.

glauca litter increased extractable soil $\mathrm{NH}_{4}^{+}$and $\mathrm{N}-$ mineralization rates in both June and August measurement periods. $\mathrm{N}$ mineralization was higher overall in June than August (time effect) and was more affected by litter in June (time $\times$ litter effect, $F_{1,27}=6.533, P=$ 0.017). However, neither litter nor live $T . \times$ glauca affected soil extractable $\mathrm{PO}_{4}{ }^{3-}$ or SOM (Table 1, Fig. 6).

Light penetrating to the soil surface was very significantly reduced by litter, from $70 \%$ of full sunlight in no-litter-no-Typha plots to $1 \%$ in litter plots (Table 1, Fig. 6). Light was not affected by live Typha.

Effects of $\mathrm{T} . \times$ glauca on the plant community.-As with effects on the abiotic environment, all significant plant community effects were brought about by the litter treatment, not by live $T . \times$ glauca (Table 1). Litter somewhat reduced species diversity and dramatically reduced total stem density by almost $75 \%$ compared to the no-litter plots (Table 1, Fig. 7). This was true at the species level as well; for 23 out of the 26 species (doubletons and singletons excluded) litter reduced stem densities by $32-100 \%$. Only three forbs increased in absolute abundance with the litter treatment. In contrast, the presence of litter resulted in taller native vegetation by a mean of $8 \mathrm{~cm}$ compared to no-litter treatment plots (Fig. 7).

CCA ordination of species composition and post hoc tests showed that Typha litter, but not live Typha or the interaction, significantly affected the plant community (Fig. 8). Despite overall reduction in stem density by litter, species varied in their extent of depression by litter (Fig. 8). A few of the dominant and common wetland species increased slightly in relative abundance (Schoenoplectus americanus, Juncus balticus, and Carex aquatilis) or were unaffected (Eleocharis smallii, E. 
erythropoda, J. nodosus, S. validus, and S. acutus) by litter addition. However, 10 species were relatively negatively affected by litter, including the common species $J$. alpinus, J. articulatus, C. viridula, C. hystericina, and E. pauciflora.

We compared species responses to litter from the 2005 transplant experiment to the 2003 survey to assess whether the litter treatment produced realistic community consequences. The species scores along the litter axis from the survey ordination (CCA) were positively correlated with those from experiment ordination $(R=$ $0.409, P=0.046, n=18$; one outlier was removed). Thus, species that were more positively associated with litter in the survey were also more positively associated with litter in the experiment.

Effects of T. $\times$ glauca litter on $\mathrm{T} . \times$ glauca growth Litter did not affect the density of $T . \times$ glauca stems, with $23.8 \pm 3.1$ vs. $26.8 \pm 1.2$ stems in the no-litter vs. litter treatments (Table 1$)$. However, $T . \times$ glauca stems grew taller when grown in the litter plots: their maximum height increased by $18.5 \mathrm{~cm}$ (Table 1, Fig. 9).

\section{Spatial heterogeneity and block effects}

Significant block effects in almost all of the analyses (Table 1) indicate considerable spatial heterogeneity in both the environmental properties and the plant community. This is not surprising because the blocks were intentionally situated over a $0.5 \mathrm{~km}$ stretch of the marsh, to test the effect of $T . \times$ glauca in a variety of different abiotic environments and plant assemblages. However, most heterogeneity in nutrient properties $\left(\mathrm{NH}_{4}{ }^{+}, \mathrm{N}\right.$ mineralization, $\mathrm{PO}_{4}{ }^{3-}$, and $\mathrm{SOM}$ ) was due to one block that had high clay content and higher elevation (no standing water) compared to other blocks. Excluding this block from the analyses eliminated or weakened block effects without greatly changing litter treatment effects on soil nutrient properties. Heterogeneity in native species density and diversity among the blocks was driven by water depth. When water depth was added as a covariate to the ANOVAs, block effects became nonsignificant or weaker, again without greatly changing the effect of the litter treatment. Heterogeneity in native vegetation maximum height was due to a block dominated by the tall Schoenoplectus acutus; excluding this block from the analysis removed block effects, while litter remained significant. Overall, much of the heterogeneity in environmental and plant community variables was explained by other variables that were measured in this study or by taking single "outlier" blocks out of the analysis. Nevertheless, including covariates or excluding outliers did not change the strong effects of the litter treatment and the lack of effect of the live treatment.

\section{Controls for pretreatment clipping}

Because all experimental plots were clipped prior to treatment, we compared an additional control plot (clipping control) to the no-live-no-litter (treatment control) plot to assess the effect of this pretreatment
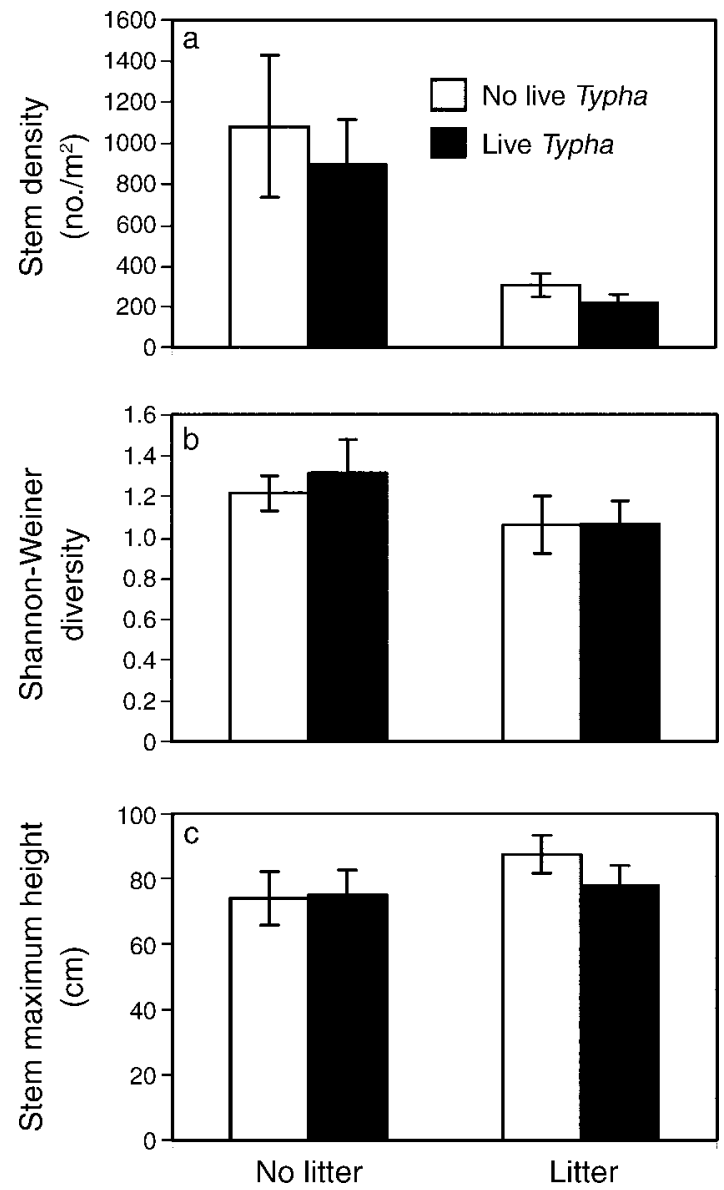

FIG. 7. Effect of transplanted T. $\times$ glauca plants and litter on (a) stem density, (b) species diversity, and (c) maximum stem height of the native vegetation (mean $\pm \mathrm{SE}, n=10$ replicates). For ANOVA results see Table 1.

clipping on the environment and plant community. Most environmental and plant measurements were unaffected by this initial clipping, except for light, stem density, and native plant height. The no-live-no-litter treatment plots had significantly more light penetration (70\%) compared to the clipping control plots $\left(39 \%, F_{1,9}\right.$ $=36.19, P<0.001)$. Although we did not measure stem density in the clipping control plots, it appeared to be reduced substantially in the no-live-no-litter treatment plots by $\sim 50 \%$. The lower stem density and more light in the clipped experimental plots is not surprising, because they had not grown back to full cover nor had substantial native litter accumulated after only one growing season. Despite this significant effect of clipping, the treatment effects of Typha litter on these two variables were so dramatic that results would not change qualitatively if plots were not clipped. Also, the native vegetation was shorter by $20 \%$ in the no-live-nolitter treatment control than in the clipping control plots $\left(F_{1,9}=20.46, P=0.001\right)$, however Typha litter effects on this variable were also small (an increase of $10 \%$ ). 


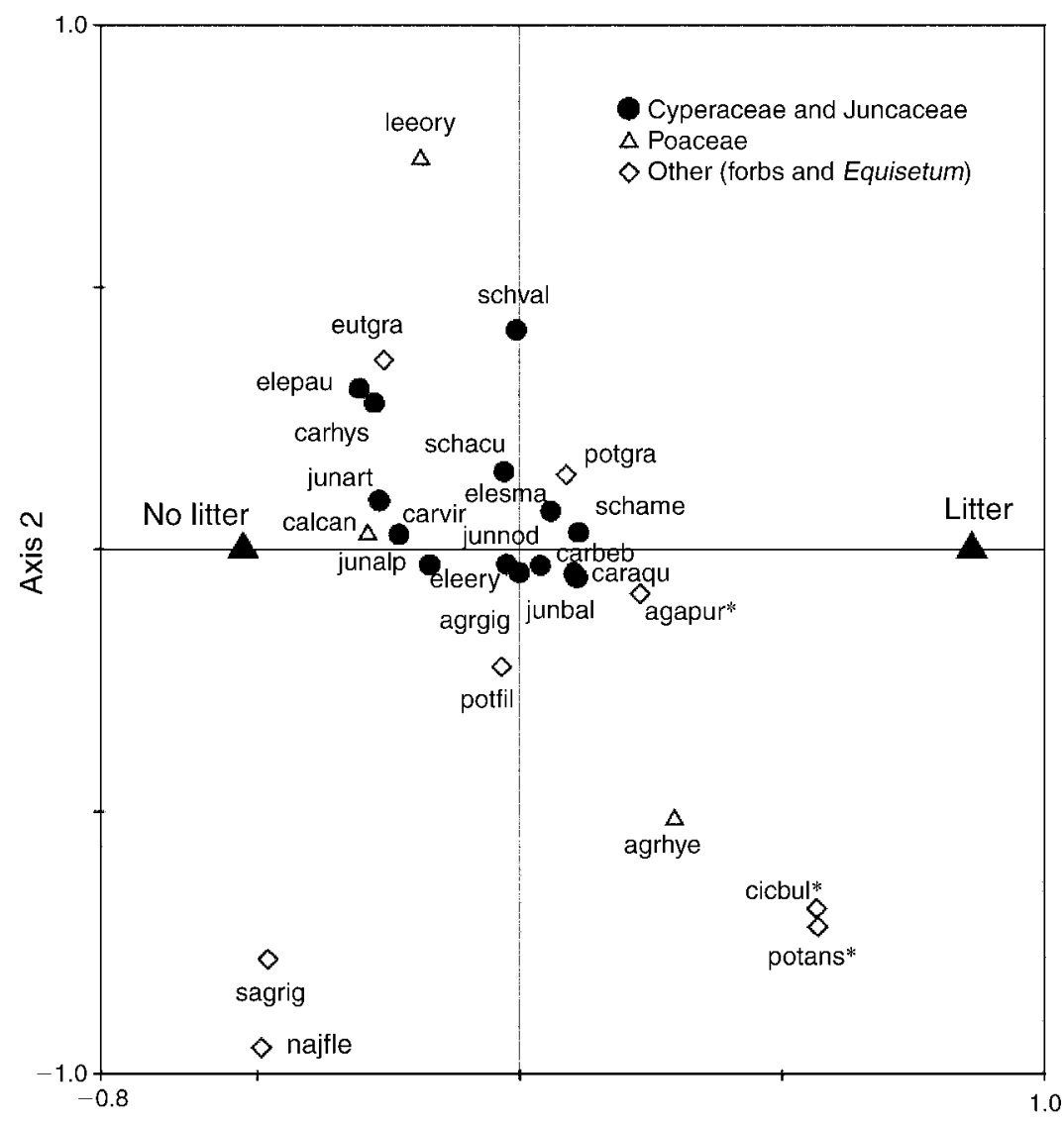

Axis 1

FIG. 8. Biplot of treatments and species scores from the CCA ordination of native species relative densities in the experimental plots. All 26 species are shown. Species with asterisks showed an increase in absolute abundance with the litter treatment as well as relative abundance. Axes 1 and 2 explain $3.0 \%$ and $6.0 \%$ of the total floristic variation, respectively. All treatment variables (litter, live, litter $\times$ live) together explained $4.5 \%$ of the floristic variation, while block explained $67.5 \%$. Litter was the only treatment that explained a significant amount of the floristic variation by itself $(3.0 \%)$; live $T . \times$ glauca and live $\times$ litter interaction had no significant effect on species composition. Abbreviations for species names are as in Fig. 5 with the following additions: agrgig, Agrostis gigantea; agrhye, Agrostis hyemalis; carbeb, Carex bebbii; cicbul, Cicuta bulbifera; eleery, Eleocharis erythropoda; eutgra, Euthamia graminifolia; leeory, Leersia oryzoides; najfle, Najas flexilis; sagrig, Sagittaria rigida.

\section{DisCuSSION}

Elevated nutrients, invasion, and native species loss

The association of elevated nutrients, invasion, and native species loss is common in many wetland systems with many different wetland invaders, including Phragmites australis, Phalaris arundinacea, and Typha domingensis (Galatowitsch et al. 1999, Meyerson et al. 2000, Childers et al. 2003, Kercher et al. 2007). Our results from the survey of Typha $\times$ glauca invasion are also consistent with this association, but only if the relationship is mediated by litter. Typha $\times$ glauca density was positively associated with high soil nutrients; however, native diversity and species composition were related only to litter and nutrient levels, not invader stem density. The positive association between $T$. $\times$ glauca density and deep litter and the observation that most of the deep litter in the marsh is from Typha, suggests that $T$. $\times$ glauca affects native species nontrophically through litter production.

We tested these non-trophic interactions, as well as competition and invader-directed environmental

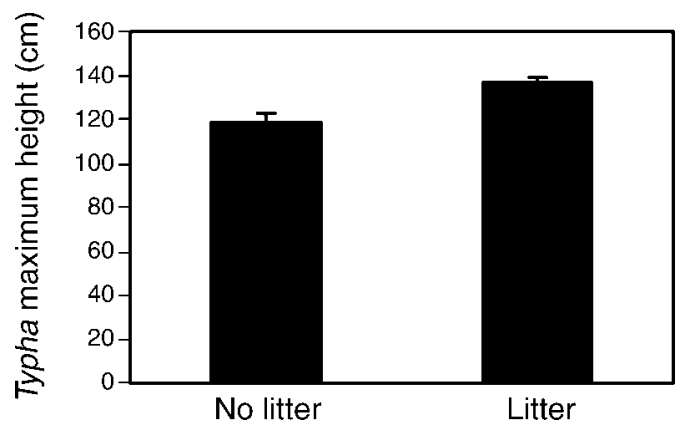

FIG. 9. Maximum height of T. $\times$ glauca transplants in nolitter and litter-addition plots (means $+\mathrm{SE}, n=10$ ). For ANOVA results see Table 1 . 
change, with a transplant experiment in order to begin to assess some of the possible causal pathways linking elevated nutrients, invasion, and native species loss (Fig. 1). The results suggest that invaders can drive environmental change, because transplanted $T . \times$ glauca litter increased soil $\mathrm{NH}_{4}^{+}$and rates of $\mathrm{N}$ mineralization. No evidence was found for resource competition between live $T . \times$ glauca and the native plant community; however, non-trophic effects were apparent because $T$. $\times$ glauca litter decreased light and decreased native-plant density and diversity and altered community composition by decreasing relative abundances of common wetland rushes and sedges. These results suggest that invaders can drive environmental change once they reach a new habitat. The survey, as well as results from N. C. Tuchman, P. Geddes, D. Larkin, R. Wildova, K. J. Jankowski, and D. E. Goldberg (unpublished manuscript), indicates that $T . \times$ glauca is able to disperse to and establish in oligotrophic marshes and microhabitats. Therefore, model 5 is a potential pathway that may explain elevated nutrients, invasion, and native species decline in this system (Fig. 1). Model 3 may occur as well, as anthropogenic inputs have been demonstrated in some invaded systems (Davis and Ogden 1994, Drexler and Bedford 2002).

Many of the worst wetland invaders in North America, Phragmites australis, Phalaris arundinacea, Typha domingensis, and T. angustifolia, share characteristics with $T . \times$ glauca, such as tall stature, fast growth rate, clonality, and litter production and accumulation. Thus, it is plausible that the mechanisms behind $T . \times$ glauca's association with elevated soil nutrients (litter production/decomposition) and low species diversity (litter accumulation/light reduction) may be applicable to the other wetland invaders as well. Interestingly, Lythrum salicaria is a notable exception, with highly decomposable leaves leading to little litter accumulation (Emery and Perry 1996); therefore changes in diversity associated with Lythrum invasion may not be mediated through litter. Next, we discuss the two components, nutrient increase and native decline, of the invaderdirected pathway supported by this study (model 5) and their implications both for this system and for wetland invaders more broadly.

\section{Mechanisms behind invader-directed nutrient increase}

Wetland invaders are commonly associated with increased nitrogen cycling (Ehrenfeld 2003), which has been attributed to oxygen release by the invader (Phragmites australis; Windham and Lathrop 1999, Windham and Ehrenfeld 2003), oxygen and exudate release (Phalaris arundinacea; Edwards et al. 2006), and SOM quality and quantity (Lythrum salicaria; Fickbohm and Zhu 2006). Studies in upland systems have also found that invasives are often associated with increased soil nitrogen mineralization due to their higher litter quality or quantity (Ehrenfeld 2003). However, all of these previous studies (with the single exception of the constructed wetland of Edwards et al. [2006]) are correlative, and the mechanism actually causing the effect was not experimentally manipulated or measured.

Consistent with previous reports, our survey data indicated that soil nutrients $\left(\mathrm{NH}_{4}{ }^{+}, \mathrm{PO}_{4}{ }^{3-}, \mathrm{SOM}\right), T . \times$ glauca density, and litter depth were all positively correlated. The experiment suggests that the mechanism underlying this pattern could be the high litter production of the invader, which in turn increases extractable $\mathrm{N}$ and $\mathrm{N}$ mineralization rates, rather than any effect of live plants. While the experimental addition of litter did not result in significant increases in $\mathrm{SOM}$ and $\mathrm{PO}_{4}{ }^{3-}$ within a year after deposition, such effects may well appear over the long term, as the litter is further decomposed and incorporated into the soil (Schlesinger 1997, Bridgham et al. 1998).

The rapidity with which the litter-addition treatment increased extractable $\mathrm{N}$ and mineralization rate might seem surprising because most litter-bag studies see an initial period of immobilization rather than mineralization after deposition (Schlesinger 1997, Windham and Ehrenfeld 2003). However, these studies follow immobilization in the litter itself rather than in the underlying soil, as we did in this study. We hypothesize that the $T$. $\times$ glauca litter may be leaching labile organic compounds to the pore water of the sediments below. Consistent with this hypothesis, preliminary sampling of pore water showed that litter plots had significantly higher dissolved organic carbon and total dissolved nitrogen (but not dissolved organic nitrogen) compared to plots without litter (and live $T . \times$ glauca had no effect; E. C. Farrer, unpublished data); however, more extensive sampling is necessary. This short-term positive effect of litter addition on nutrient cycling rates has not been observed in forest manipulations (Holub et al. 2005), but it may be more common in wetlands because standing water tends to accelerate fragmentation, decomposition, and transport of litter leachate to the soil (Welsch and Yavitt 2003). Although this leaching process may be short term, each season the addition of fresh litter as Typha plants senesce will provide the soil with leachate; thus this mechanism of nutrient increase may be particularly important in early stages of invasion.

Long-term litter dynamics may also lead to increases in soil nutrient availability. Typha and other wetland invasives are highly productive, generating large quantities of litter which are large stores of organic N. We suggest that Typha litter will also increase soil nutrient availability in the long term through the release of the $\mathrm{N}$ from the litter via mineralization and through its incorporation into SOM, which is an $\mathrm{N}$ source and increases cation exchange capacity.

Interestingly, live $T . \times$ glauca plants do not affect nutrient cycling or nutrient pools, even though stem densities in experimental plots are similar to those found in $T$. $\times$ glauca monocultures in the field. Therefore, neither resource depletion due to uptake nor facilitation of $\mathrm{N}$ cycling due to oxygenation or root exudates 
(Windham and Lathrop 1999, Windham and Ehrenfeld 2003, Edwards et al. 2006) appears to be important in this system.

\section{Mechanisms behind decline in native species}

Live $T . \times$ glauca plants in the experiment do not affect native species density, diversity, or species composition. Moreover, neither nutrients nor light is reduced by live plants, suggesting that resource competition (i.e., column 2 in Fig. 1, Competition from invader) is not a likely mechanism of native species decline in this system. Light limitation is commonly thought to be important in native species decline in wetlands either because the invader is taller than the natives (Lenssen et al. 2000, Drexler and Bedford 2002, Woo and Zedler 2002) or because of the growth/allocation behavior of the native plants when grown with the invader (Green and Galatowitsch 2002, Minchinton and Bertness 2003). In most studies, however, light levels are not measured, and because light reduction also depends on leaf arrangement and orientation as well as stem density, height comparisons alone are insufficient to infer light limitation (Güsewell and Edwards 1999).

In contrast, non-trophic effects through litter (column 3 in Fig. 1, "Invader change in environment") seem to be the primary mechanism of reduction in native density and diversity and changes in species composition. Nontrophic effects of invasive plants are not considered by most invasive-species studies, despite litter being recognized as an important factor in structuring native plant communities (Facelli and Pickett 1991, Xiong and Nilsson 1999). Only two previous field experiments on invasive species ( $T$. angustifolia and Phragmites australis) have manipulated litter independently of live plants (Hager 2004, Minchinton et al. 2006). Our results and the results of both previous studies suggest that suppression of growth is at least as strong by litter as by live plants. Negative effects of litter on plant establishment and growth is likely due either to light reduction ( $98 \%$ in our study) and/or to physical obstruction of growth (Lenssen et al. 2000).

\section{Positive feedbacks}

When a plant affects environmental conditions, these effects are likely to feed back to influence the performance of that plant (Bever et al. 1997, Van Breemen and Finzi 1998, Ehrenfeld et al. 2005). A feedback is positive if a plant modifies the environment in a way that benefits itself, by increasing its population or individual growth (Ehrenfeld et al. 2005). Positive feedbacks may be a very effective mechanism of invasion (Ehrenfeld 2003, Levine et al. 2006), and positive feedbacks through nutrient dynamics have been hypothesized as a mechanism of invasion for Berberis thunbergii and Microstegium vimineum in deciduous forests (Ehrenfeld et al. 2001), Bromus tectorum invasion in arid grasslands (Sperry et al. 2006), as well as a number of invaders in Hawaii (Allison and Vitousek 2004).
Feedbacks can be incorporated into the framework of models presented in Fig. 1. When the invader affects the environment, this influences native species, as shown by the arrow from the environment to the natives. However, this environmental change also affects the invader's own growth; therefore, an arrow should also point from the environment back to the invader (this was not included in Fig. 1 for simplicity). The results from this study suggest that $T . \times$ glauca may produce a positive feedback through its litter. Although Typha litter had no effect on $T$. $\times$ glauca stem density, it significantly increased the growth of individual $T . \times$ glauca stems, possibly due to the increased $\mathrm{N}$ under the litter. Thus, high litter production by $T . \times$ glauca seems to create a high-nutrient-low-light environment, which benefits itself.

The low light under large amounts of litter does not negatively affect $T . \times$ glauca, probably due to its large rhizomes compared to native species, which provide substantial energy reserves allowing new shoots to quickly grow through the shaded litter layer. Also, $T$. $\times$ glauca stems have a large diameter and are relatively stiff when young, so new shoots would be able to push through the obstructing litter layer to reach the light. Once stems penetrate the litter layer, they can take advantage of the elevated $\mathrm{N}$.

\section{Implications}

This study demonstrates that invaders can increase nutrients in wetlands and therefore act as the driver of environmental change, and that non-trophic effects can have much stronger negative effects on native plants than competition for resources. Thus, model 5 (Fig. 1) very likely contributes to $T$. $\times$ glauca invasion. Nevertheless, human-directed eutrophication could also play a role in $T . \times$ glauca invasions (i.e., model 3 in Fig. 1); the models are not mutually exclusive. Regardless of the source, increased nutrients would promote invasion due to the rapid and positive response of $T . \times$ glauca (Woo and Zedler 2002), which would in turn promote litter production and suppression of native species. Anthropogenic nutrient input may, in fact, be important in initiating the positive feedback loop by $T$. $\times$ glauca and speed the spread of the invader though the site. However, our results suggest that the decline in native species will occur only after litter builds up, via nontrophic effects.

While anthropogenic nutrient input probably can and does promote invasion by $T . \times$ glauca and consequent local-diversity decline, the results from this study indicate that it is not necessary: $T . \times$ glauca can produce a high nutrient, low-density, low-diversity wetland community all by itself. This has very different management and remediation implications than a purely human-directed invasion. For example, it indicates that a cessation of anthropogenic nutrient loading, although it may slow the process, will not prevent $T$. $\times$ glauca from expanding, elevating nutrient levels, and decreas- 
ing the diversity in wetlands. Because transplants grew well even in the low-nutrient marsh conditions (in the no-litter plots) and because of the ability of $T . \times$ glauca to invade oligotrophic sites (this study, and N. C. Tuchman et al., unpublished manuscript), even pristine wetlands, removed from anthropogenic influence, are at risk of invasion. Because of the many environmental impacts of $T . \times$ glauca, the removal of the living $T . \times$ glauca plants will not restore wetlands; nutrients will still be elevated in the soil, rhizomes and aboveground litter will continue to contribute to elevated $\mathrm{N}$ mineralization, and any remaining litter will still suppress native plant growth. Moreover, if only live $T . \times$ glauca is removed from a site, the remaining environmental conditions may make reinvasion much more likely.

The similarities in morphology, growth response, and litter production between $T$. $\times$ glauca and other large, clonal wetland invaders like Phragmites, Phalaris, and other Typha species suggest that the mechanisms behind nutrient increase and native species decline found in this study may be more broadly applicable.

\section{ACKNOWLEDGMENTS}

We thank Knute Nadelhoffer, George Kling, Nancy Tuchman, and Mike Grant for their advice and use of lab space and equipment. Mike Grant, James Le Moine, Mark Brahce, Christopher Wallace, and Eileen Quintero helped with chemical analysis. We also thank Radka Wildova, Judith Farrer, and Fredrick Farrer for field assistance. Radka Wildova, William Currie, Heather Hager, and one anonymous reviewer gave thoughtful comments on earlier drafts of this manuscript. This research was carried out at the University of Michigan Biological Station and was supported by a University of Michigan Biological Station-Nature Conservancy Fellowship and a University of Michigan Rackham Block Grant.

\section{Literature Cited}

Allison, S. D., and P. Vitousek. 2004. Rapid nutrient cycling in leaf litter from invasive plants in Hawai'i. Oecologia 141:612619.

Bever, J. D., K. M. Westover, and J. Antonovics. 1997. Incorporating the soil community into plant population dynamics: the utility of the feedback approach. Journal of Ecology 85:561-573.

Bowden, W. B. 1987. The biogeochemistry of nitrogen in freshwater wetlands. Biogeochemistry 4:313-348.

Bridgham, S. D., K. Updegraff, and J. Pastor. 1998. Carbon, nitrogen, and phosphorus mineralization in northern wetlands. Ecology 79:1545-1561.

Byers, J. E. 2002. Impact of non-indigenous species on natives enhanced by anthropogenic alteration of selection regimes. Oikos 97:449-458.

Childers, D. L., R. F. Doren, R. Jones, G. B. Noe, M. Rugge, and L. J. Scinto. 2003. Decadal change in vegetation and soil phosphorus pattern across the Everglades landscape. Journal of Environmental Quality 32:344-362.

D’Antonio, C. M., and P. M. Vitousek. 1992. Biological invasions by exotic grasses, the grass/fire cycle, and global change. Annual Review of Ecology and Systematics 23:6387.

Davis, M. A., J. P. Grime, and K. Thompson. 2000. Fluctuating resources in plant communities: a general theory of invasibility. Journal of Ecology 88:528-534.

Davis, S. M., and J. C. Ogden. 1994. Everglades: the ecosystem and its restoration. St. Lucie Press, Delray Beach, Florida, USA.
Didham, R. K., J. M. Tylianakis, M. A. Hutchison, R. M. Ewers, and N. J. Gemmell. 2005. Are invasive species the drivers of ecological change? Trends in Ecology and Evolution 20:470-474.

Drexler, J. Z., and B. L. Bedford. 2002. Pathways of nutrient loading and impacts on plant diversity in a New York peatland. Wetlands 22:263-281.

Dukes, J. S., and H. A. Mooney. 1999. Does global change increase the success of biological invaders? Trends in Ecology and Evolution 14:135-139.

Eaton, A. D., L. S. Clesceri, and A. E. Greenberg. 1995. Standard methods for the examination of water and wastewater. 19th edition. American Public Health Association, Washington, D.C., USA.

Edwards, K. R., H. Čižková, K. Zemanová, and H. Šantrǔčková. 2006. Plant growth and microbial processes in a constructed wetland planted with Phalaris arundinacea. Ecological Engineering 27:153-165.

Ehrenfeld, J. G. 2003. Effects of exotic plant invasions on soil nutrient cycling processes. Ecosystems 6:503-523.

Ehrenfeld, J. G., P. Kourtev, and W. Huang. 2001. Changes in soil functions following invasions of exotic understory plants in deciduous forests. Ecological Applications 11:1287-1300.

Ehrenfeld, J. G., B. Ravit, and K. Elgersma. 2005. Feedback in the plant-soil system. Annual Review of Environment and Resources 30:75-115.

Emery, S. L., and J. A. Perry. 1996. Decomposition rates and phosphorus concentrations of Purple Loosestrife (Lythrum salicaria) and Cattail (Typha spp.) in fourteen Minnesota wetlands. Hydrobiologia 323:129-138.

Eviner, V. T., and F. S. Chapin, III. 2003. Functional matrix: a conceptual framework for predicting multiple plant effects on ecosystem processes. Annual Review of Ecology and Systematics 34:455-485.

Facelli, J. M., and S. T. A. Pickett. 1991. Plant litter-its dynamics and effects on plant community structure. Botanical Review 57:1-32.

Fickbohm, S. S., and W. Zhu. 2006. Exotic purple loosestrife invasion of native cattail freshwater wetlands: effects on organic matter distribution and soil nitrogen cycling. Applied Soil Ecology 32:123-131.

Galatowitsch, S. M., N. O. Anderdon, and P. D. Ascher. 1999. Invasiveness in wetland plants in temperate North America. Wetlands 19:773-755.

Grace, J. B., and J. S. Harrison. 1986. The biology of Canadian weeds. 73. Typha latifolia L., Typha angustifolia L. and Typha xglauca Godr. Canadian Journal of Plant Science 66:361379.

Green, E. K., and S. M. Galatowitsch. 2001. Differences in wetland plant community establishment with additions of nitrate- $\mathrm{N}$ and invasive species (Phalaris arundinacea and Typha $\times$ glauca). Canadian Journal of Botany 79:170-178.

Green, E. K., and S. M. Galatowitsch. 2002. Effects of Phalaris arundinacea and nitrate- $\mathrm{N}$ addition on the establishment of wetland plant communities. Journal of Applied Ecology 39: 134-144.

Güsewell, S., and P. Edwards. 1999. Shading by Phragmites australis: a threat for species-rich fen meadows? Applied Vegetation Science 2:61-70.

Hager, H. A. 2004. Differential effects of Typha litter and plants on invasive Lythrum salicaria seedling survival and growth. Biological Invasions 6:433-444.

Hager, H. A., and R. D. Vinebrooke. 2004. Positive relationships between invasive purple loosestrife (Lythrum salicaria) and plant species diversity and abundance in Minnesota wetlands. Canadian Journal of Botany 82:763-773.

Hill, M. O., and H. G. Gauch. 1980. Detrended corrrespondence analysis: an improved ordination technique. Vegetatio 42:47-58.

Hobbie, S. E. 1992. Effects of plant species on nutrient cycling. Trends in Ecology and Evolution 7:336-339. 
Hobbs, R. J., and L. F. Huenneke. 1992. Disturbance, diversity, and invasion: implications for conservation. Conservation Biology 6:324-337.

Holub, S. M., K. Lajtha, J. D. H. Spears, J. A. Tóth, S. E. Crow, B. A. Caldwell, M. Papp, and P. T. Nagy. 2005. Organic matter manipulations have little effect on gross and net nitrogen transformations in two temperate forest mineral soils in the USA and Europe. Forest Ecology and Management 214:320-330.

Kercher, S. M., A. Herr-Turoff, and J. B. Zedler. 2007. Understanding invasion as a process: the case of Phalaris arundinacea in wet prairies. Biological Invasions 9:657-665.

Kuehn, M. M., J. E. Minor, and B. N. White. 1999. An examination of hybridization between the cattail species Typha latifolia and Typha angustifolia using random amplified polymorphic DNA and chloroplast DNA markers. Molecular Ecology 8:1981-1990.

Lenssen, J. P. M., F. B. J. Menting, W. H. Van der Putten, and C. W. P. M. Blom. 2000. Variation in species composition and species richenss within Phragmites australis dominated riparian zones. Plant Ecology 147:137-146.

Levine, J. M., E. Pachepsky, B. E. Y. Kendall, S. G. Yelenik, and J. H. R. Lambers. 2006. Plant-soil feedbacks and invasive spread. Ecology Letters 9:1005-1014.

Levine, J. M., M. Vilà, C. M. D'Antonio, J. S. Dukes, K. Grigulis, and S. Lavorel. 2003. Mechanisms underlying the impacts of exotic plant invasions. Proceedings of the Royal Society of London B 270:775-781.

MacDougall, A. S., and R. Turkington. 2005. Are invasive species the drivers or passengers of change in degraded ecosystems? Ecology 86:42-55.

Mack, M. C., and C. M. D'Antonio. 1998. Impacts of biological invasions on disturbance regimes. Trends in Ecology and Evolution 13:195-198.

Meyerson, L. A., K. Saltonstall, L. Windham, E. Kiviat, and S. Findlay. 2000. A comparison of Phragmites australis in freshwater and brackish marsh environments in North America. Wetlands Ecology and Management 8:89-103.

Minchinton, T. E., and M. D. Bertness. 2003. Disturbancemediated competition and the spread of Phragmites australis in a coastal marsh. Ecological Applications 13:1400-1416.

Minchinton, T. E., J. C. Simpson, and M. D. Bertness. 2006. Mechanisms of exclusion of native coastal marsh plants by an invasive grass. Journal of Ecology 94:342-354.

Newman, S., J. B. Grace, and J. W. Koebel. 1996. Effects of nutrients and hydroperiod on Typha, Cladium, and Eleocharis: implications for Everglades restoration. Ecological Applications 6:774-783.

Pederson, D. C., D. M. Peteet, D. Kurdyla, and T. Guilderson. 2005. Medieval warming, Little Ice Age, and European impact on the environment during the last millennium in the lower Hudson Valley, New York, USA. Quaternary Research 63:238-249.

Rickey, M. A., and R. C. Anderson. 2004. Effects of nitrogen addition on the invasive grass Phragmites australis and a native competitor Spartina pectinata. Journal of Applied Ecology 41:888-896.

Schlesinger, W. H. 1997. Biogeochemistry: an analysis of global change. Second edition. Academic Press, San Diego, California, USA.

Scott, N. A., S. Saggar, and P. D. McIntosh. 2001. Biogeochemical impact of Hieracium invasion in New Zealand's grazed tussock grasslands: sustainability implications. Ecological Applications 11:1311-1322.

Smith, S. G. 1987. Typha: its taxonomy and the ecological significance of hybrids. Archiv für Hydrobiologie-Ergebnisse der Limnologie 27:129-138.

Sperry, L. J., J. Belnap, and R. D. Evans. 2006. Bromus tectorum invasion alters nitrogen dynamics in an undisturbed arid grassland ecosystem. Ecology 87:603-615.

Stuckey, R. L., and D. P. Salamon. 1987. Typha angustifolia in North America: a foreigner masquerading as a native. American Journal of Botany 74:757.

Suding, K. N., K. L. Gross, and G. R. Houseman. 2004. Alternative states and positive feedbacks in restoration ecology. Trends in Ecology and Evolution 19:46-53.

Svengsouk, L. J., and W. J. Mitsch. 2001. Dynamics of mixtures of Typha latifolia and Schoenoplectus tabernaemontani in nutrient-enrichment wetland experiments. American Midland Naturalist 145:309-324.

ter Braak, C. J. F. 1987. CANOCO-A FORTRAN program for canonical community ordination by (partial) (detrended) (canonical) correspondence analysis, principal components analysis, and redundancy analysis (version 2.1). TNO Institute for Applied Computer Science, Statistics Department, Wageningen, the Netherlands.

ter Braak, C. J. F. 1990. Update notes: CANOCO version 3.10. Agricultural Mathematical Group, Wageningen, the Netherlands.

ter Braak, C. J. F., and P. Smilauer. 1998. CANOCO reference manual and user's guide to CANOCO for Windows: software for canonical community ordination. Version 4. Microcomputer Power, Ithaca, New York, USA.

ter Braak, C. J. F., and P. F. M. Verdonschot. 1995. Canonical correspondence analysis and related multivariate methods in aquatic ecology. Aquatic Science 57:255-289.

Van Breemen, N., and A. C. Finzi. 1998. Plant-soil interactions: ecological aspects and evolutionary implications. Biogeochemistry 42:1-19.

Waters, I., and J. M. Shay. 1990. A field study of the morphometric response of Typha glauca shoots to a water depth gradient. Canadian Journal of Botany 68:2339-2343.

Waters, I., and J. M. Shay. 1992. Effect of water depth on population parameters of a Typha glauca stand. Canadian Journal of Botany 70:349-351.

Welsch, M., and J. B. Yavitt. 2003. Early stages of decay of Lythrum salicaria $\mathrm{L}$. and Typha latifolia $\mathrm{L}$. in a standing-dead position. Aquatic Botany 75:45-57.

Windham, L., and J. G. Ehrenfeld. 2003. Net impact of a plant invasion on nitrogen-cycling processes within a brackish tidal marsh. Ecological Applications 13:883-897.

Windham, L., and R. G. Lathrop. 1999. Effects of Phragmites australis (common reed) invasion on aboveground biomass and soil properties in brackish tidal marsh of the Mullica River, New Jersey. Estuaries 22:927-935.

Woo, I., and J. B. Zedler. 2002. Can nutrients alone shift a sedge meadow towards dominance by the invasive Typha $\times$ glauca? Wetlands 22:509-521.

Xiong, S., and C. Nilsson. 1999. The effects of plant litter on vegetation: a meta-analysis. Journal of Ecology 87:984-994.

Zedler, J. B., and S. Kercher. 2004. Causes and consequences of invasive plants in wetlands: opportunities, opportunists, and outcomes. Critical Reviews in Plant Sciences 23:431-452. 